\title{
Production, Proximate and Sensory Evaluation of Rhynchophorus Phoenicis (F) Larva Paste
}

\author{
Kiin-Kabari D.B. (Corresponding author) \\ Department of Food Science and Technology \\ Rivers State University of Science and Technology, P.M.B 5080, Port Harcourt, Nigeria \\ Ogbonda K.H \\ Department of Biological Sciences \\ Rivers State University of Education \\ P.M.B 4047, Rumuolumeni, Port Harcourt, Nigeria \\ E-mail: kabaridavid@yahoo.com
}

Received: Dec 23, 2012

Accepted: January 14, 2013 Published: June 1, 2013

doi:10.5296/jfs.v2i1.2938

URL: http://dx.doi.org/10.5296/jfs.v2i1.2938

\begin{abstract}
Rhynchophorus phoenicis (F) larva was used in the production of Rhynchophorus larva paste. The paste was then used as fillers in the preparation of pies and sandwich. Both the paste and products (pies and sandwich) were evaluated for proximate composition and sensory parameters and compared to commercial meat pies and sandwich. High level of moisture content of $20.10 \%$ (R. paste), $32.4 \%$ in the R. pie, and $30.2 \%$ in the commercial meat pie were observed. There was a significant difference between the moisture content of $\mathrm{R}$. sandwich (33.6\%) and commercially produced sandwich $(26.8 \%)$. The R. Paste was high in protein content $(20.45 \%)$ and improved significantly the protein content of R. pies $(16.4 \%)$ when compared to commercial meat pies (12.4\%), the energy value of the R. paste was high $498.83 \mathrm{kcal} / \mathrm{g}$ of paste. This was due to high fat content of $45.42 \%$ which also increased the fat content of the products (19.6\% for R. pies and 16.3\% for R. sandwich )compared to $7.2 \%$ and $5.4 \%$ for R. sandwich compared to $7.2 \%$ and $5.4 \%$ for commercial meat pies and sandwiches respectively. There was no significant difference in colour between the R. pie and the C-meat pies, however, a significant difference was observed in taste compared to the commercial products tested. The Rhynchophrus phoenicis (F) larva paste was generally accepted as a filter in pie production than sandwich.
\end{abstract}

Keywords: Larva paste, Fillers, Meat pies, Sandwich, Proximate and sensory Evaluation 


\section{Introduction}

Insects are used as human food in many parts of the world. In some developing countries, it is viewed with aversion but elsewhere, it is seen as a wise utilization of natural resources because insects form a greater part of the phylum arthropods which dominates the animal kingdom. The larva of the beetle Rhynochophorus phoenicis (F) is cherished as food among the many communities in Nigeria (Okaranye and Ikewuchi, 2008) and around the world especially in those places where palms (oil, raphia and coconut) are cultivated (Defoliat, 1992; Choon-Fah et al, 2008).

Ekrakene and Igeleke (2007) reported that in the Niger Delta region and Eastern States of Nigeria, the Larva is a cherished delicacy and can be seen hawked along major roads, markets and motor packs in Edo and Delta States of Nigeria. In 1976, Oliveira et al studied the nutritional compositions of four insect including Rhynchophorus phoenicis and they observed that it was high in fat and protein. They reported that the larvae are rich sources of animal fat, most valuable sources of unsaturated fatty acids. Okaranye and Ikewuchi (2008) observed a high protein value of $31.61 \%$ wet basis with a protein score of $72.97 \%$. They concluded that the protein of the larvae is rich in essential amino acids, high in methionine, histidine and phenylalanine while limiting only in valine. Nzikou et al (2010) reported that the larva as a good source of minerals with sodium $(832.59 \pm 03 \mathrm{mg} / 100 \mathrm{~g})$ as the highest, followed in descending order by magnesium $(132.7 \pm 0.20 \mathrm{mg} / 100 \mathrm{~g})$; calcium $(72.4 \pm 0.22$ $\mathrm{mg} / 100 \mathrm{~g})$ and potassium $(22.89 \pm 1.7 \mathrm{mg} / 100 \mathrm{~g})$.

In view of the nutritional qualities of Rhynchophorus phoenicis (F) larva and the high level of consumption of this larvae in the Niger Delta region of Nigeria, this study is therefore aimed at the production of the larvae into a paste, investigating the utilization of the paste as a filler for pies and sandwich and finally to evaluate the sensory and general acceptability of the products (pies and sandwich) when compared to commercially produced samples.

\section{Materials and Methods}

Sources of Larvae: The $R$. phoenicis larvae used in this study was obtained by harvesting wild infested raffia palms (Raffia hookesi) and oil palm (Elacis quinensis) of the swampy tropical rain forest around Port Harcourt metropolis of Rivers State and Anyama-Ijaw community of Southern-Ijaw Local Government of Bayelsa State, all belonging to the palm belt of the Niger Delta Area of South South region of Nigeria.

The trunks of the infested palms were cut open using a sharp axe and machete. The larvae were harvested manually from the tunnels by hand as reported by Thomas et al (2006) and transported in aerated plastic containers together with their wet/moist feed of raffia palm pit to the Food science and Technology laboratory Rivers State University of Science and Technology, Port Harcourt for preparation.

Preparation of the R. Phoenicis Larva Paste: The method of Thomas et al (2006) was used with modifications, 30 grams of ground larvae, $2 \mathrm{~g}$ of crayfish, and other ingredients were added as shown in Table 1. The mixture was fried in heated vegetable oil with constant stirring for 5 minutes, six portions of the paste labelled A - F were prepared, portions A, B 
and $\mathrm{C}$ was used as pie fillers while D and $\mathrm{E}$ was used as sandwich filler. The portion used for proximate composition of paste was prepared using the same method.

Preparation of Rhynchophorus Pie and Sandwich: $200 \mathrm{~g}$ of flour was prepared as shot pastry, $100 \mathrm{~g}$ of R. paste was used to replace minced meat. Other ingredient such as carrots $(50 \mathrm{~g})$ potatoes $(100 \mathrm{~g})$, Onions $(50 \mathrm{~g})$ were added. The pastry was oven-baked at a temperature of $130^{\circ} \mathrm{C}$ for 40 minutes while the sandwich was prepared using a sandwich toaster.

Sensory Evaluation: The R. Phoenicis larva pastes pies and sandwiches were presented alongside with commercially produced meat pies and sandwich to a panel of 20 semi-trained evaluators consisting of staff and students of the Rivers State University of Science and Technology Port Harcourt and who are familiar with the $R$. Phoenicis larvae. The products were scored for colour, flavour, paste and general acceptability using a 5 - point hedonic scale with $5=$ like extremely and $1=$ dislike extremely.

Proximate Composition of Paste, Pie and Sandwich: Moisture content, crude fat (ether extract), crude protein were determined on the paste, R. pies and R. sandwich according to the AOAC (1990) standard methods, whereas total carbohydrate content was done using the anthrone method as reported by Osbone and Voogt (1978). Energy values were calculated using the Atwater energy factor. Commercial - meat pies and sandwich was also evaluated alongside with the products.

Statistical Analysis: All data from the experiment were analysed in triplicates and means subjected to analysis of variance (Iwe 2002). Where a significant F-test was noticed, means were separated using Duncan's multiple range test. Significance was accepted at $\mathrm{P} \leq 0.05$.

\section{Result and Discussion}

The proximate composition of the Rhynhophorus phoenicis (F) larva paste, (R. paste, Rhychophorus pies and R. sandwich as presented in table 2 showed no significant difference in moisture content between the larva paste used as a pie filler (R. pie) and the commercially produced meat pie (C. meat pie). The moisture content ranges from $20.10 \%$ for R. paste to $33.6 \%$ for R. Sandwich. However, there was a significant difference between the R. sandwich (33.6\%) and the commercially produced sandwich (26.8\%). These levels of moisture in both the R. pies and R. sandwich prepared from the paste may poise stability problems because of its susceptibility to micro-organisms. This observation is in agreement with the report of Uraih and Izuagbe, (1990). The ash content of R. pastes and products are shown in Table 2. There was high ash value of $8.32 \%$ obtained in the Rhychophorus larva paste. This observation is in agreement with the report of Okaraonye and Ikewuchi (2008) who also reported a high ash value because of the mineral content of the larva. The protein content of the larva ranged from $20.45 \%$ in the Rhynchophorus paste and decreased to $9.9 \%$ observed in the commercial sandwich. However, there was a significant difference in protein content between Rhynchophorous larva paste pie (16.4\%) and the commercial meat pie (11.2\%). This same trend was also observed between Rhychophorous larva sandwich (12.4\%) and the commercial sandwich (9.9\%). This implies that Rhynchophorous phoenicis larva paste can contribute significantly to the daily human protein requirements, usually about $23-56 \mathrm{~g}$ (FAO, 


\section{Macrothink

1991; Chaney, 2006). Although the carbohydrate content of the paste (2.2\%), it increased significant when used as a filler in Rhychophorous larva paste pie. (20.6\%). The developed paste (R. paste) has high energy value of $498.83 \mathrm{kcal} / \mathrm{g}$. this observation agreed with the report of Oliveria et al, (1976) who had earlier reported that $R$. phoenicis larvae is nutritious with a high energy value of $239.9 \mathrm{~kg} / 100 \mathrm{~g}$ of larvae.

Table 3 shows the mean scores for sensory evaluation of $R$. phoenicis larva pie (R. pie) and R. larvae sandwich ( $\mathrm{R}$-sandwich) compared with commercially prepared meat pies (C-meat pie) and sandwich (C-sandwich). The results showed that there was no significant difference in colour between the R. pie and the commercial meat pie, however, there was a significant difference in taste in R. pie and R. sandwich compared to the commercial products. This may be due to the strong $R$. phoenicis larva flavour and other ingredients used in the preparation of the paste. The Rhynchophorus phoenicis larva paste was generally accepted as filler in meat pie than for sandwich.

\section{Conclusion}

The Rhynchophorus phoenicis (F) larvae paste was produced and successfully used in the preparations of $R$. phoenicis pie and R. sandwich as fillers. The R. paste improved the protein content of the pie. However, the Rhynchophorus pies were preferred, further work on the storage stability of the developed paste and the pies are in progress.

\section{References}

AOAC. (1990). Official method of Analysis Association of Analytical Chemist, $11^{\text {th }}$ Edition, Washington DC.

Chaney, S.G. (2006). Principles of Nutrition 1: Macronutrients In Textbook of Biochemistry with clinical correlat, Devlin T.M (Ed) John Wiley and Sons, New York, pp. 1090.

Choon-Fah, J.B; E. Chin-Chin, Y. Pang-Hung \& R. Amartalingam. (2008). Growth performance of the red - striped weevil Rhynchophorus schach, Oliv (Insecta: Coleoptera; curculioniclae) on meridic diets Am. J. Agric. Biol. Sci, 3, 403-409.

Defoliart, G. (1992). A concise summary of the general nutritional value of insects. http//www.food-insects.com/insects as human food.htm.

Ekrakene, T., \& C.L Igbeleke. (2007); Microbial Isolates from the roasted larva of the palm weevil (Rhyochophorus phoenicis) (F) from Edo and Delta States of Niigeria Am .J. Biol. Applied Sci. 1: 763 - 768.

FAO/WHO. (1991). Energy and protein requirements: Report of a joint FAO/WHO/UNU expert consultation. WHO Technical Report Series 724.

Iwe, M.O. (2002). Handbook of Sensory methods and Analysis, Rejoint Communication Services Ltd. Enugu. Pp 64-70.

Nzikon, J.M, Mbanba F, Mvoula-Isieri M, Diabangouaya-Batela B, Malela K.E, Kimbonguala A, Ndangui C.B, Pambon - Tobi N.P, Silon Th., \& Desobys. (2010). 


\section{Macrothink Institute ${ }^{\mathrm{TM}}$}

Characterization and Nutritional Potentials of Rhynchophorus larva consumed in Congo-Brazzaville. Journal of Biological Science, 2(3), 189-194.

Okaraonye C.C., \& Ikewuchi J.C. (2008); Rhynchoporus phoenicis (F) larvae meal, Nutritional value and Health Implications. J. Biol. Sciences, 8, 1221-1225. http://dx.doi.org/10.3923/jbs.2008.1221.1225

Oliverira S.F, de Carva/ho J.P, de Sacsa R, de Bruno, \& Simao M.M, (1976). The Nutritional value of four species of insects consumed in Angola. Ecology of food and Nutrition (s) 91-97. http://dx.doi.org/10.1080/03670244.1976.9990450

Osborne D. R., \& Vooat. (1978). The Analysis of Nutrients in foods. Academic Pres Publishers (Inc) Ltd U.K.

Thomas C.N, Achinewhu S.C, Ogbalu O.K, Okwakpam B.A., \& Kiin-Kabari D.B. (2006). Production of Rhynchophorus Phoenicis larvae Recipe for Human Consumption. Niger Delta Biologia, 6(1), 131-134.

Uriah N. \& Y. Izuagbe (1990); Public Health, food and industrial microbiology $1^{\text {st }}$ Edn, Uniben Press, Nigeria. ISBN: 978-2027-00-6.

Table 1. Recipe for R. Phoenicis Larvae Paste

\begin{tabular}{|c|c|c|c|c|c|c|c|c|c|}
\hline Sample & $\begin{array}{c}\text { Quantity of } \\
\text { Larvae } \\
\mathbf{( g )}\end{array}$ & $\begin{array}{c}\text { Cray- } \\
\text { fish } \\
\mathbf{( g )}\end{array}$ & $\begin{array}{c}\text { Salt } \\
\mathbf{( g )}\end{array}$ & $\begin{array}{c}\text { Onion } \\
\mathbf{( g )}\end{array}$ & $\begin{array}{c}\text { Maggi } \\
\mathbf{( g )}\end{array}$ & $\begin{array}{c}\text { Fresh } \\
\text { Pepper } \\
\mathbf{( g )}\end{array}$ & $\begin{array}{c}\text { Tinned } \\
\text { Toma- } \\
\text { toes }\end{array}$ & $\begin{array}{c}\text { Veg } \\
\text { Oil } \\
\mathbf{m l}\end{array}$ & $\begin{array}{c}\text { Water } \\
\mathbf{m l}\end{array}$ \\
\hline $\mathrm{A}$ & 30 & 2 & 0.5 & 8.30 & 0.5 & 2.31 & 3.62 & 15 & 20 \\
$\mathrm{~B}$ & 30 & 2 & 0.5 & 8.30 & 0.5 & 2.31 & 3.62 & 15 & 20 \\
$\mathrm{C}$ & 30 & 2 & 0.5 & 8.30 & 0.5 & 2.31 & 3.62 & 15 & 20 \\
$\mathrm{D}$ & 30 & 2 & 0.5 & 8.30 & 0.5 & 2.31 & 3.62 & 15 & 20 \\
\hline E & 30 & 2 & 0.5 & 8.30 & 0.5 & 2.31 & 3.62 & 15 & 20 \\
\hline
\end{tabular}

Source: Thomas et. $\underline{\text { al; }}$ (2006). 


\section{Macrothink}

Table 2. Proximate Composition of R. Phoenicis (F) larvae Paste, Pie and Sandwich.

\begin{tabular}{|l|c|c|c|c|c|c|}
\hline \multicolumn{1}{|c|}{ Sample } & $\begin{array}{c}\text { Moisture } \\
\text { content } \\
\text { \% }\end{array}$ & $\begin{array}{c}\text { Ash } \\
\mathbf{\%}\end{array}$ & $\begin{array}{c}\text { Fat } \\
\mathbf{\%}\end{array}$ & $\begin{array}{c}\text { Protein } \\
\mathbf{\%}\end{array}$ & $\begin{array}{c}\text { Carbohy-d } \\
\text { rate } \\
\text { \% }\end{array}$ & $\begin{array}{c}\text { Energy } \\
\text { Kcal/g }\end{array}$ \\
\hline R. Paste & $20.10^{\mathrm{c}}$ & $8.32^{\mathrm{a}}$ & $45.42^{\mathrm{a}}$ & $20.45^{\mathrm{a}}$ & $2.2^{\mathrm{d}}$ & $498.83^{\mathrm{a}}$ \\
\hline R. Pie & $32.4^{\mathrm{a}}$ & $7.2^{\mathrm{b}}$ & $19.6^{\mathrm{b}}$ & $16.4^{\mathrm{b}}$ & $20.6^{\mathrm{c}}$ & $326.77^{\mathrm{b}}$ \\
\hline R. Sandwich & $33.6^{\mathrm{a}}$ & $7.8^{\mathrm{a}}$ & $16.3^{\mathrm{c}}$ & $12.4^{\mathrm{c}}$ & $32.6^{\mathrm{a}}$ & $324.68^{\mathrm{b}}$ \\
\hline C. Meat Pie & $30.2^{\mathrm{a}}$ & $8.1^{\mathrm{a}}$ & $7.2^{\mathrm{c}}$ & $11.2^{\mathrm{c}}$ & $27.8^{\mathrm{b}}$ & $217.13^{\mathrm{d}}$ \\
\hline C. Sandwich & $26.8^{\mathrm{b}}$ & $7.7^{\mathrm{a}}$ & $5.4^{\mathrm{d}}$ & $9.9^{\mathrm{c}}$ & $40.6^{\mathrm{a}}$ & $243.06^{\mathrm{c}}$ \\
\hline
\end{tabular}

Figure with the same superscript within the same column do not differ significantly.

Table 3. Mean Score for Sensory Evaluation of R. Phoenicis Larva Pie and Larva Sandwich

\begin{tabular}{|l|c|c|c|c|}
\hline \multicolumn{1}{|c|}{ Sample } & Colour & Flavour & Taste & $\begin{array}{c}\text { General } \\
\text { Acceptability }\end{array}$ \\
\hline R. Pie & $4.1^{\mathrm{a}}$ & $3.6^{\mathrm{a}}$ & $4.2^{\mathrm{a}}$ & $3.9^{\mathrm{a}}$ \\
\hline R. Sandwich & $3.0^{\mathrm{b}}$ & $3.4^{\mathrm{b}}$ & $3.9^{\mathrm{a}}$ & $3.6^{\mathrm{a}}$ \\
\hline C. Meat Pie & $4.2^{\mathrm{a}}$ & $3.8^{\mathrm{a}}$ & $3.5^{\mathrm{b}}$ & $3.7^{\mathrm{a}}$ \\
\hline C. Sandwich & $3.1^{\mathrm{b}}$ & $3.0^{\mathrm{c}}$ & $3.6^{\mathrm{b}}$ & $3.4^{\mathrm{b}}$ \\
\hline
\end{tabular}

Figures with the same superscript within the same column do not differ significantly. 